\title{
Detection of Aeromonas salmonicida in wild Atlantic salmon using a specific DNA probe test
}

\author{
Jenny Mooney, Eithne Powell, Catherine Clabby, Richard Powell*
}

Recombinant DNA Group, Department of Microbiology, University College Galway, Ireland

\begin{abstract}
The presence of Aeromonas salmonicida, the etiological agent of furunculosis, was examined using polymerase chain reaction (PCR) and DNA probe methodology in wild Atlantic salmon Salmo salar taken from 3 Irish river systems. Blood samples from 61 individual fish were examined and the presence of pathogen was determined in $87 \%$ of the fish examined. However, the level of pathogen was extremely low, calculated at less than $100 \mathrm{~A}$. salmonicida genome equivalents per fish. These data imply a widespread low level infection of $A$. salmonicida amongst wild salmon in lrish rivers.
\end{abstract}

KEY WORDS: Aeromonas salmonicida. DNA probe- Atlantic salmon

\section{INTRODUCTION}

Aeromonas salmonicida is the etiological agent of furunculosis, a disease that affects salmonids and related species (Popoff 1984, Trust 1986, Austin \& Austin 1993). Furunculosis was first reported in many European countries, including Ireland, in the early $1900 \mathrm{~s}$ and in the last $20 \mathrm{yr}$ has recieved considerable attention with the development of Atlantic salmon aquaculture. Studies analysing outbreaks of furunculosis in wild salmon have led to the consideration that this disease is enzootic in the rivers of Great Britain (Austin \& Austin 1987). A similar consideration may also apply to Irish rivers. The confirmation of enzootic status is relevant for both the commercial salmon industry and the monitoring and maintenance of native stocks. However, the absence of an efficient selective medium and the poor plating efficiency of this organism in mixed cultures has curtailed our ability to examine the ecology of $A$. salmonicida and the epizootiology of furunculosis.

Previous reports of DNA probes specific for Aeromonas salmonicida have stated their potential as a valuable aid, with great sensitivity and with no culture requirements, in studying this organism (Barry

\footnotetext{
- Addressee for correspondence
}

et al. 1990, Gustafson et al. 1992). We described a specific DNA probe for $A$. salmonicida and, coupled with $\mathrm{PCR}$, a diagnostic test with a sensitivity limit of approximately $100 \mathrm{~A}$. salmonicida genome equivalents when used to examine fish tissues or marine water and sediment samples (Hiney et al. 1992, Mooney et al. 1993). Similarily, this DNA probe appeared useful in detecting nonculturable but viable $A$. salmonicida cells in mixed lake water populations (Morgan et al. 1993). The genetic locus of the probe is a $6.4 \mathrm{~kb}$ cryptic plasmid known to occur in $90 \%$ of $A$. salmonicida ss salmonicida isolates (Sørum et al. 1993). This locus is also found in all $A$. salmonicida ss achromogens strains tested, some A. salmonicida ss masouscida strains and some A. salmonicida atypical strains. No reaction has been found with over 60 related aeromonads and aquatic bacteria tested to date. Here we report the use of this test to determine the presence or absence of A. salmonicida in wild Atlantic salmon.

For the purpose of this study, 61 wild Atlantic salmon parr were collected from 3 separate river systems in Ireland (Moy, Slaney, and Shannon). Neither the Moy nor the Slaney system has been stocked with hatcheryreared fish, although small salmon and rainbow trout hatcheries exist on the Slaney system. The lower Shannon system has a yearly restocking programme with fin-clipped smolts and parr. However, taking into account the restocking programme, the fish collected 
at the sampling site were considered to be the result of natural spawning. Cursory examination of the fish revealed no obvious external signs of infection. DNA was extracted from fish blood and checked for its suitability as a substrate for PCR by amplifying a salmonspecific microsatellite DNA sequence. Following amplification of this salmon genome sequence, the fish samples were tested for the presence of Aeromonas salmonicida DNA using a pathogen-specific PCR with subsequent verification by DNA hybridisation.

\section{MATERIALS AND METHODS}

Collection and preparation of fish blood. Wild salmon were collected from the river systems in Ireland in August 1993 by electrofishing. Naturally spawned $1+\operatorname{parr}(n=22)$ from the river Bann, on the Slaney system; $1+$ parr $(n=19)$ from the river Bunree on the Moy system; and $0+\operatorname{parr}(n=20)$ from the Shannon river system were included in the study. The fish included in the study had not yet migrated from the rivers in which they had spawned. Aproximately 10 to $100 \mu \mathrm{l}$ of blood was extracted from the dorsal vein of each fish using a sterile needle and syringe. Each sample was placed into a sterile $50 \mathrm{ml}$ Sarstedt tube for DNA extraction.

Extraction of DNA. The cells in each sample were initially lysed by increasing the sample volume to $5 \mathrm{ml}$ with lysis buffer. Lysis buffer was $10 \mathrm{mM}$ Tris- $\mathrm{HCl}$ $(\mathrm{pH} \mathrm{7.5),2} \mathrm{mM} \mathrm{MgCl}, 10 \mathrm{mM}$ EDTA, $400 \mathrm{mM} \mathrm{NaCl}$, $10 \%$ SDS and Proteinase $\mathrm{K}$ (final concentration of $0.2 \mathrm{mg} \mathrm{ml}^{-1}$ ) (Boehringer Mannheim $\mathrm{GmbH}$, Germany). This mixture was incubated at $37^{\circ} \mathrm{C}$ overnight on a rotary shaker. After cell lysis, an equal volume of phenol (Tris-HCl-equilibrated, $\mathrm{pH} 7.5$ ) and chloroform (24:1 chloroform-isoamylalcohol) was added and mixed well. After heating at $65^{\circ} \mathrm{C}$ for $10 \mathrm{~min}$, the mixture was centrifuged at $4000 \times g$ for $5 \mathrm{~min}$. The top layer, containing the nucleic acids, was removed and a double volume of ice-cold absolute ethanol was added to precipitate the DNA. A sterile pipette tip was then used to spool out the DNA into a sterile $1.5 \mathrm{ml}$ microcentrifuge tube, and, after vacuum drying, the DNA was suspended in $150 \mu$ l autoclaved $\mathrm{H}_{2} \mathrm{O}$ (analar grade, BDH, Poole, UK). Samples $(10 \mu l)$ of the DNA preparation from each of the fish blood samples were analysed for both quality and quantity by electrophoresis on $1 \%$ agarose gel. Comparison with $\lambda$ Hind III DNA molecular weight standards revealed intact large molecular weight DNA with concentrations ranging from 10 to $100 \mu \mathrm{g} \mathrm{II}^{-1}$ Each DNA preparation was then diluted with analar water to a final concentration of $5 \mathrm{ng} \mathrm{ul}^{-1}$ before use as a template for PCR

PCR suitability test. To ensure the extracted DNA was of sufficient quality and was free of PCR inhibitors, each DNA sample was subjected to a PCR suitability test using primers which amplify a 121 bp fragment from the Atlantic salmon genome. The amplification reaction mixture contains $10 \mathrm{mM}$ Tris- $\mathrm{HCl}(\mathrm{pH} 8.5)$, $50 \mathrm{mM} \mathrm{KCl}, 1.5 \mathrm{mM} \mathrm{MgCl}, 200 \mu \mathrm{M}$ of each of the deoxynucleosides dATP, dGTP, dTTP and dCTP (Promega Corporation, Madison, WI, USA). Fifty ng of each of the primers (F431: 5'-AGCGGCATAACGTGCTGTGT and F432: 5'-GAGTCACTCAAAGTGAGGCC) and 1.0 U Taq Polymerase (Promega Corp.) was added per reaction. Two $\mu \mathrm{l}(10 \mathrm{ng})$ of the extract to be tested was added and the total volume was brought up to $50 \mu \mathrm{l}$ with water. A negative control with $2 \mu \mathrm{l}$ of water replacing the target DNA and a positive control containing $10 \mathrm{ng}$ of a plasmid clone DNA containing the microsatellite sequence were also included. Touchdown cycling conditions (Don et al. 1991) were carried out: 5 cycles at an annealing temperature of $65^{\circ} \mathrm{C}, 10$ cycles with an annealing temperature of $60^{\circ} \mathrm{C}$, and finally 20 cycles with an annealing temperature of $55^{\circ} \mathrm{C}$. In all cases, DNA denaturation was carried out $20 \mathrm{~s}$ at $96^{\circ} \mathrm{C}$, followed by the specified annealing temperature for $20 \mathrm{~s}$, and finally $30 \mathrm{~s}$ at $72^{\circ} \mathrm{C}$ for primer extension. Amplifications were performed in sterile 500 ul PCR microcentrifuge tubes (Perkin Elmer Cetuis, Norwalk, CT, USA) in a programmable thermocycler (Omnigene TR3 CM220, Hybaid Ltd, UK). Following amplification, $10 \mu \mathrm{l}$ of the $50 \mu \mathrm{l}$ reaction mixture were analysed by gel electrophoresis on a $3.0 \%$ agarose gel, with a 121 bp DNA fragment expected from a positive amplification.

Aeromonas salmonicida-specific PCR. Following a positive result for PCR suitability, the extracts were subjected to an $A$. salmonicida-specific PCR. The reaction mixture consisted of $10 \mathrm{mM}$ Tris- $\mathrm{HCl}(\mathrm{pH} 8.5)$, $50 \mathrm{mM} \mathrm{KCl}, 1.5 \mathrm{mM} \mathrm{MgCl}, 200 \mathrm{mM}$ of each dNTP, $1 \mathrm{U}$ Taq polymerase, $200 \mathrm{ng}$ of each of the primers (PAAS 1: 5'-CGTTGGATATGGCTCTTCCT and PAAS 2: 5'CTCAAAACGGCTGCGTACCA), and $2 \mu \mathrm{l}$ (10 ng) of the sample DNA preparation. The volume was brought up to $100 \mu \mathrm{l}$ with water. As for the PCR suitability test, both a negative (no template) and a positive control (10 ng purified A. salmonicida DNA) were included. PCR cycling conditions were $96^{\circ} \mathrm{C}$ for 1 min (denaturation), $55^{\circ} \mathrm{C}$ for $1 \mathrm{~min}$ (primer annealing), and $72^{\circ} \mathrm{C}$ for 1 min (extension). Thirty-five cycles were carried out at these temperatures followed by $5 \mathrm{~min}$ at $72^{\circ} \mathrm{C}$. The PCR products were electrophoresed on a $1 \%$ agarose gel, with a $423 \mathrm{bp}$ fragment indicating a positive result.

Aeromonas salmonicida-specific nested-PCR. To increase sensitivity, nested PCRs were carried using the internal primers PAAS 4 (5'-AGGTAAGTCTATTAGGTTCG) and PAAS 5 (5'-GTTACACTTTTTCCTTCCGC). Both these primers are designed to correspond to internal sequences in the $423 \mathrm{bp}$ 
PAAS1/PAAS2 primed amplification product. Two $\mu 1$ of the original PCR product was used as the target template for these nested PCRs. All other constituents in the reaction mixture were as for the original PCR. Cycling conditions were the same except for a lower annealing temperature of $45^{\circ} \mathrm{C}$. Upon gel electrophoresis, a fragment of $278 \mathrm{bp}$ was expected from a positive amplification.

Hybridisation with an internal DNA probe. Electrophoresis gels containing the original and nested PCR products were Southern blotted onto Hybond-N membrane. One hundred ng of the oligodeoxynucleotide (PAAS 3: 5'-GCTAGCCAACTCTCTTTCCA), which corresponds to a nucleotide sequence internal to both the 423 bp PCR fragment and the 278 bp nestedPCR fragment, was end-labeled with $\gamma$ - $\mathrm{P}^{32}$ ATP using 1 $\mathrm{U} \mathrm{T}_{4}$ Polynucleotide kinase. The labelled probe was purified through a low salt/high salt DE-52 anion exchange column. Hybridisation was carried out at $45^{\circ} \mathrm{C}$ overnight, followed by washes with $5 \times \mathrm{SSC}(3 \mathrm{M}$ sodium chloride, $0.3 \mathrm{M}$ sodium citrate), $0.1 \% \mathrm{SDS}$ at room temperature, then with $1 \times \mathrm{SSC}, 0.1 \% \mathrm{SDS}$ at room temperature. The filters were exposed onto Agfa X-OMAT AR X-ray film for $12 \mathrm{~h}$.

\section{RESULTS}

\section{PCR suitability test}

Agarose gel analysis revealed the sucessful amplification of a $121 \mathrm{bp}$ DNA fragment from all fish DNA samples (see Fig. 1 for the Moy samples) using the salmon-specific F431 and F432 primers. This indicated that the DNA in the extracts was amenable to PCR with no amplification inhibitors present. All sample preparations were then deemed suitable for amplification using the Aeromonas salmonicida-specific primers.

\section{Aeromonas salmonicida-specific PCR and nested PCR}

Amplification with the Aeromonas salmonicida-specific primers, PAAS 1 and PAAS 2, which results in the production of a $423 \mathrm{bp}$ DNA fragment, was performed on all fish samples, and $10 \mu \mathrm{l}$ of the PCR was analysed by electrophoresis on a $1.0 \%$ agarose gel. Despite sucessful amplification with the positive control (10 ng for purified $A$. salmonicida DNA), no amplification products were apparent from any of the fish samples. However, Southern blot and hybridisation analysis of the apparently negative gel analysis revealed that 5 of the fish samples from the Moy river system gave a faint positive signal after probing with the internal oligodeoxynucleotide (PAAS3) as described in 'Materials and methods' (data not shown). Our experience suggests that this level of detection corresponds to the presence of approximately 100 to 500 pathogen genome equivalents in the prepared sample (Mooney et al. 1993).

In an attempt to increase the sensitivity of detection, a nested PCR was performed on the products of the original PCR. Of the original PCR mixture, $2 \mu \mathrm{l}$ was used as the substrate for a second amplification reaction using 2 new primers (PAAS 4 and 5) which correspond to sequences internally coded and separated by $278 \mathrm{bp}$ in the $423 \mathrm{bp}$ DNA fragment expected from the original PCR. Again, $10 \mu \mathrm{l}$ of this nested PCR was analysed by electrophoresis on a $1.0 \%$ agarose gel. The results revealed that $87 \%$ of the fish samples showed amplification of the $278 \mathrm{bp}$ fragment by gel electrophoresis analysis. Twenty of the 22 fish from the river Bann, 17 of the 20 fish from the Shannon, and 16 of the 19 fish from the Moy (Fig. 2) were positive. As a confirmatory test, these nested PCR products were Southern blotted and probed with the confirmatory internal oligodeoxynucleotide (PAAS 3). The hybridisation results (Fig. 3 ) revealed that all the amplification products of the nested PCRs were of Aeromonas salmonicdia origin, thus confirming the presence of this pathogen in these samples. Also, 3 of the nestedPCR amplification products, 1 from each river system, were further analysed by sequence elucidation. No sequence difference was found amongst the amplified 278 bp DNA fragments.

\section{DISCUSSION}

We describe methodology for the extraction of DNA from fish blood samples of sufficient quality for examination with PCR. Specifically, PCR methodology was used to examine these samples for the presence of the pathogenic bacterium Aeromonas salmonicida. This methodology was used to study wild fish samples collected from 3 geographically distinct Irish river systems (northwest, west and east Ireland). The results obtained suggest the presence of low levels of $A$. salmonicida in the majority $(87 \%)$ of native Atlantic salmon in these river systems. The level of pathogen present in these fish is difficult to quantify with rigour, but the fact that a nested PCR procedure was required to positively determine pathogen presence (except for 5 fish from the Moy which gave a low reaction with the original PCR) strongly suggests that less than $100 \mathrm{~A}$. salmonicida cells were present in the positive samples.

It is of interest that this level of pathogen was determined in blood, suggesting that infection by Aeromonas salmonicida had occurred in these fish. 
$\begin{array}{lllllllllllllll}1 & 2 & 3 & 4 & 5 & 6 & 7 & 8 & 9 & 10 & 11 & 12 & 13 & 14 & 15\end{array}$

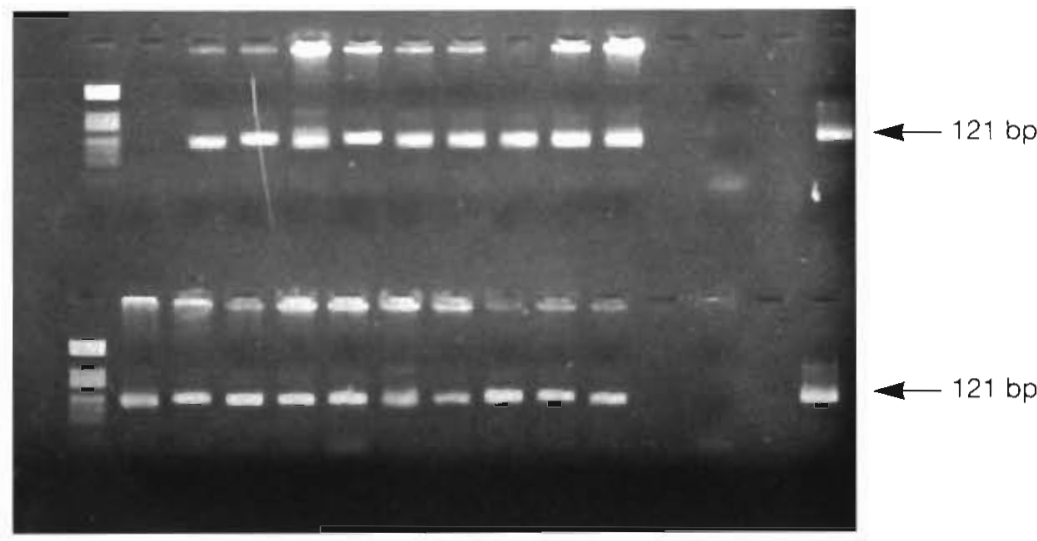

$\begin{array}{lllllllllllllll}1 & 2 & 3 & 4 & 5 & 6 & 7 & 8 & 9 & 10 & 11 & 12 & 13 & 14 & 15\end{array}$

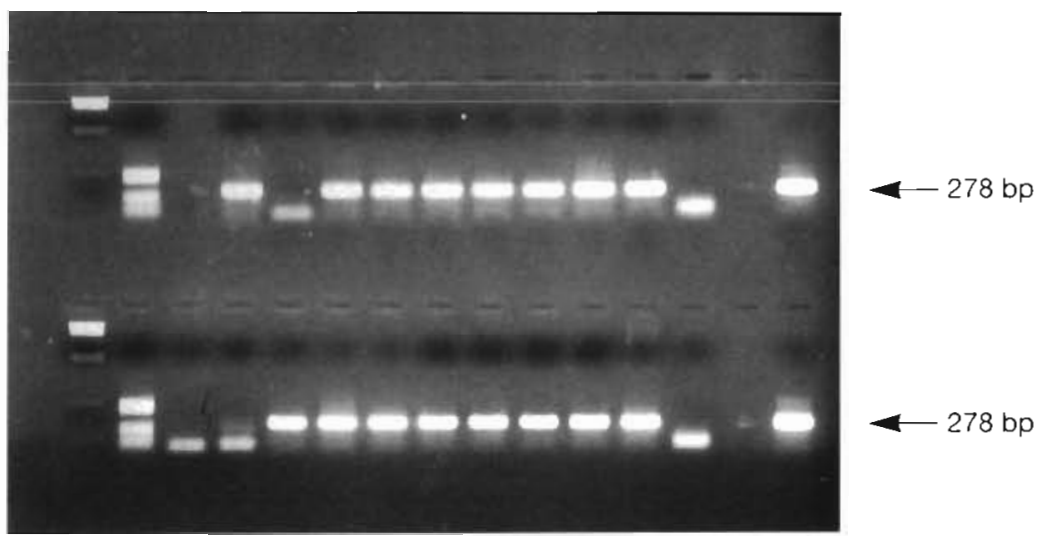

Fig 2.1.0\% agarose gel stained with ethidium bromide. The 278 bp PCR product resulting from the nested PCR using the PAAS 4 and PAAS 5 primers is indicated. Top wells: (1) $\lambda$ Hind III molecular weight marker; (2) pBR322 Hae III molecular weight marker; (4 to 12) fish samples 1 to 9 from the Moy; (13) negative control; (15) positive control. Bottom wells: (1) גHind III molecular weight markeri (2) pBR322 Hae III molecular weight marker; (3 to 12) fish salmples 10 to 19 from the Moy; (13) PCR negative control using no DNA template; (15) PCR positive control using $10 \mathrm{ng}$ Aeromonas salmonicida DNA.

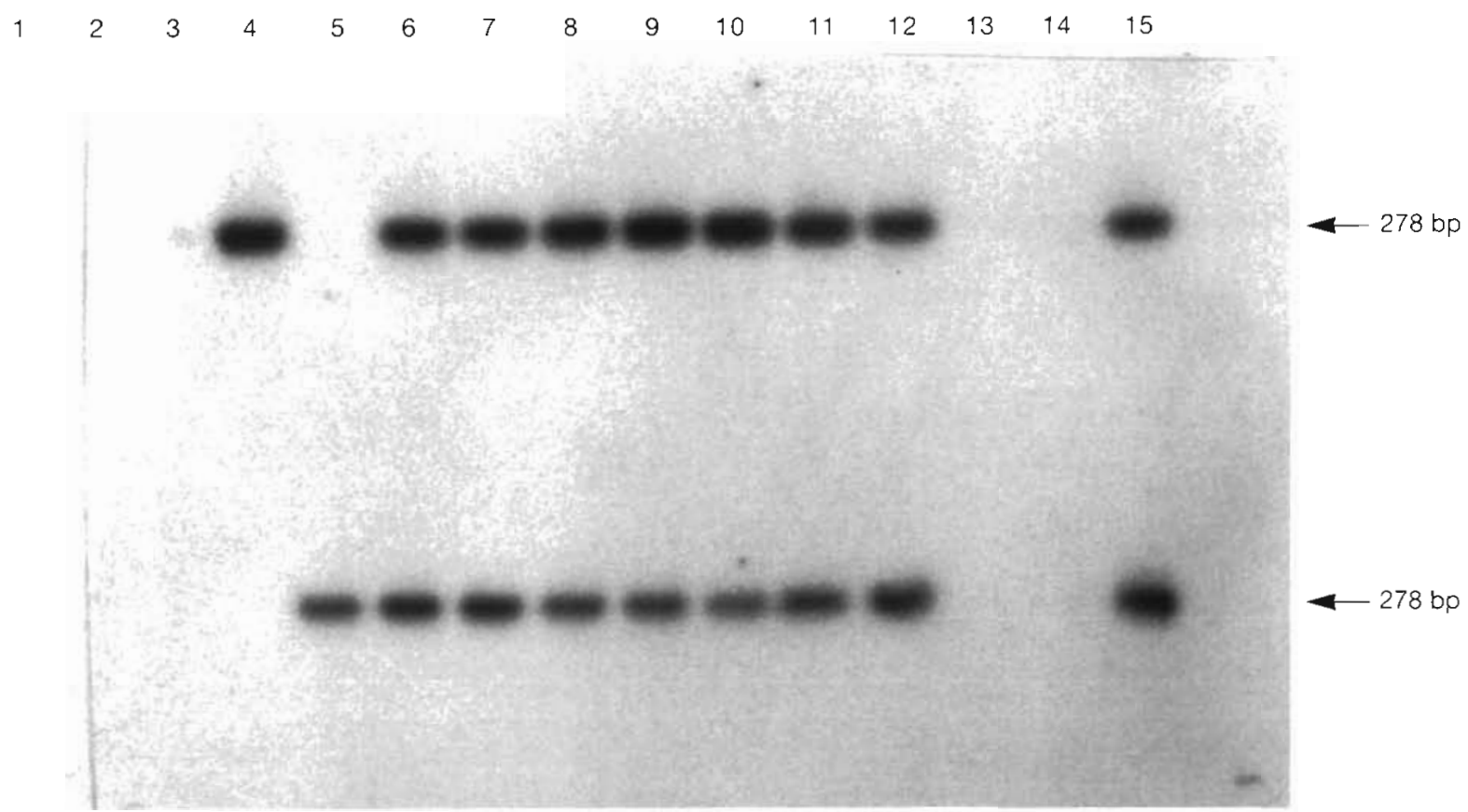

Fig. 3. Southern blot of nested PCR products probed with a radıolabelled internal oligonucleotıde (PAAS 3). Top wells: (1) $\lambda$ Hind III molecular weight marker; (2) pBR322 Hae III molecular weight marker; (4 to 12) fish samples 1 to 9 from the Moy; (13) negative control (15) positive control. Bottom wells: (1.) $\lambda$ Hind III molecular weight marker; (2) pBR322 Hae lll molecular weight marker; ( 3 to 12 ) fish samples 1.0 to 19 from the Moy; (13) PCR negative control using no DNA template; (15) PCR posituve control using $10 \mathrm{ng}$ Aeromonas salmonucida UNA. 
Whether this level of pathogen is significant in relation to the subsequent appearance of clinical furunculosis in these fish cannot be answered by this study. A second observation of note is that this DNA-based detection methodology requires only the presence of A. salmonicida DNA for positive reaction. This may not equate with viable pathogen cells circulating in the fish bloodstream. Nevertheless, these data present evidence for a widespread low level infection of $A$. salmonicida amongst native Irish Atlantic salmon stocks. '

Acknowledgements. We thank all our colleagues in the Recombinant DNA Group at University College Galway; the staff of the Central. North-Western and Eastern Fisheries Boards; and M. O'Farrell and W. O'Connor of the Fisheries Conservation Unit, Hydro Group, Electricity Supply Board This work has been supported by the E.C. AIR programme (AIR-CT92-0308-Development of Management Strategies to Control Disease of Commercially Farmed Fish).

\section{LITERATURE CITED}

Austin B, Austin DA (1987) Aeromonads. In: Austin B, Austin DA (eds) Bacterial fish pathogens: disease in farmed and wild fish. Ellis Horwood Ltd, Chichester, p 111-195

Austin B, Austin DA (1993) Aeromonadaceae representatives (Aeromonas salmonicida). In: Austin B, Austin DA (eds) Bacterial fish pathogens: disease in farmed and wild fish.

Responsible Subject Editor: T. Evelyn, Nanaimo, B.C., Canada 2nd edn. Ellis Horwood Ltd, Chichester, p 86-170

Barry T, Powell R, Gannon F (1990) A general method to obtain DNA probes for microorganısms. Bıotechnology 8: $233-236$

Don RH, Cox PT, Wainwright BJ, Baker K, Mattıck JS (1991) Touchdown PCR to prevent spurious primıng during gene amplification. Nuclerc Acids Res 19:4008

Gustafson CE, Thomas CJ, Trust TJ (1992) Detection of Aeromonas salmonicida from fish by using polymerase chain reaction of the virulence surface array protein gene. Appl environ Microbiol 58:3816-3825

Hiney M, Dawson MT, Heery DM, Smith PR, Gannon F, Powell R (1992) DNA probe for Aeromonas salmonicida. Appl environ Microbiol 58:1039-1042

Mooney J, Ryan D, O'Brien D, Powell R (1993) PAAS: a DNA probe based diagnostic test for the detection of Aeromonas salmonicida in environmental samples. In: Proc 6 th EAFP Meet, Diseases of fish and shellfish, Brest, France, September 5-10, p 35

Morgan JAW, Rhodes G, Pickup RW (1993) Survival of nonculturable Aeromonas salmonicida in lake water. Appl environ Microbiol 59:874-880

Popoff M (1984) Genus III Aeromonas Kluyver \& van Neil 1936, 398 ${ }^{\mathrm{AL}}$ In: Krieg NR (ed) Bergey's Manual of Systematic Bacteriology, Vol 1 Williams and Wilkins, Baltimore. p 545-548

Sorum H, Kvello JH, Håstein T (1993) Occurrence and stability of plasmids in Aeromanas salmonicida ss salmonicida isolated from salmonids with furunculosis. Dis aquat Org 16:199-206

Trust TJ (1986) Pathogenesis of infectious diseases of fish. A Rev Microbiol 40:479-502

Manuscript first received: January 14, 1994

Revised version accepted: October 21, 1994 